\title{
Environmental management and the poverty monitoring in the subjects of the Russian Federation
}

\author{
Irina Omelchenko ${ }^{1}$, Oleg Dozortzev ${ }^{1}$, Marina Danilina ${ }^{1,2,3,{ }^{*}}$, Alexander Vas'kov ${ }^{1}$, Olga \\ Selivanova ${ }^{1}$, Tatiana Vartanyanz ${ }^{1}$ \\ ${ }^{1}$ Research Institute VNII of Labor, Ministry of Labour of Russia, Zemlyanoy Val, 34, 105064 , \\ Moscow, Russia \\ ${ }^{2}$ Finance University under the Government of the Russian Federation, Leningradsky prosp., 49, \\ 125993 Moscow, Russia \\ ${ }^{3}$ Russian Economic University, Stremyanny per., 36, 117997 Moscow, Russia
}

\begin{abstract}
The degradation of the natural world undermines efforts to eradicate poverty, scientists warn and note that the only chance for global prosperity for all countries is to recognize the fight against poverty as an environmental challenge. The most important driver for achieving environmental sustainability is the fight against poverty. It is generally accepted that poverty is a consequence of environmental degradation. On the basis of the materials from 77 constituent entities of the Russian Federation the authors determined that the provided regional action plans to achieve the national goal of halving the poverty level is not sufficient and propose the additional list of measures to achieve this goal. The authors propose the methods for calculating the target value of the poverty level indicator (the level of the population with incomes below the subsistence level and the distribution of target persons across the constituent entity of the Russian Federation.
\end{abstract}

\section{Introduction}

The existing environmental situation and trends in its change are largely determined by industrial production and economic activity in general. Despite some successes and achievements, the overall picture continues to deteriorate here. The main reason for this is the low efficiency of the used mechanisms of environmental control and management in industrial production. The need to search for new ways and approaches to solving environmental problems of industrial production is becoming more and more obvious. Environmental management is generally recognized as the main such way in the world. Environmental management is part of the overall corporate governance system, which has a clear organizational structure and aims to achieve the provisions specified in the environmental policy through the implementation of environmental protection programs.

* Corresponding author: marinadanilina@yandex.ru 
Organizations of various kinds are becoming increasingly interested in achieving and demonstrating sufficient environmental performance by monitoring the environmental impact of their activities, products or services, taking into account their environmental policies and environmental targets. They are doing this in the face of increasingly stringent legislation, the development of economic policies and other measures aimed at protecting the environment, as well as a general increase in stakeholder concerns about the environment, including sustainable development.

As concerns about preserving and improving the quality of the environment and protecting human health grow, organizations of all sizes are paying increasing attention to the potential impacts of their activities, products or services on the environment.

The environmental performance of an organization is becoming increasingly important to internal and external stakeholders. Achieving high environmental performance requires an organization to commit itself to a systematic approach and continual improvement of its environmental management system.

An environmental management system is a modus operandi for industry, necessary to achieve environmental policy goals and step-by-step solution of specific tasks.

There is a clear parallel between the requirements for the organization of the TQM (Total Quality Management) system and the EMS environmental management system. Note that the core of the management philosophy in developed countries is considered to be a comprehensive quality system (TQM), which is aimed at efficiently obtaining high-quality products and services (through the entire life cycle - from raw materials through production to the life of the product itself and the final disposal of waste).

Today, humans are increasingly transforming the planet in a way that could undermine any progress made. Research shows that the stable functioning of the Earth's systems, including the atmosphere, oceans, forests, waterways, biodiversity and biogeochemical cycles, is a prerequisite for a thriving global society. Further inaction will lead to irreversible changes in the Earth's major systems: water shortages, extreme weather conditions, deteriorating conditions for food production, ecosystem losses, ocean acidification and sea level rise are real threats that can threaten development and trigger a humanitarian crisis throughout the world.

As the world's population grows, the pressure on local ecosystems increases.

The degradation of the natural world undermines efforts to eradicate poverty, scientists warn and note that the only chance for global prosperity for all countries is to recognize the fight against poverty as an environmental challenge. The most important driver for achieving environmental sustainability is the fight against poverty. It is generally accepted that poverty is a consequence of environmental degradation. This result was announced in the Brundtland report [1] and the Millennium Development Goals report. [2]

According to the Brundtland report, "Poverty is one of the effects of global environmental problems. In this regard, it is necessary to fight environmental problems, to have an understanding of the causes of poverty and international inequality." [1] People living in poverty rely more on local ecosystems for basic resources (food and medicine) and general well-being. [3]

In this regard, it is advisable to study the problems of poverty in Russia and propose solutions to reduce it.

\section{Materials and methods}

The authors use the methods of content-analysis and statistical methods in order to analyze the materials from 77 constituent entities of the Russian Federation. At the moment the 
provided regional action plans to achieve the national goal of halving the poverty level is not sufficient.

1) Analysis of action plans of the subjects of the Russian Federation to achieve the national goal of halving the poverty level

As part of the analysis, materials from 77 constituent entities of the Russian Federation were examined, which provided regional action plans to achieve the national goal of halving the poverty level. The research was realized in 2019, presenting the forecast for 2024 .

The measures proposed by a number of constituent entities of the Russian Federation seem to be insufficient to improve the existing situation with the poverty level. For example, in the Kemerovo region, it is planned to implement measures to increase labor productivity, create and modernize highly productive jobs, retrain citizens of pre-retirement age, assist in improving the qualifications of workers, in finding a suitable job.

However, specific measures are not presented, all formulations are vague. According to Rosstat, in 2018 there were 80 thousand unemployed in the Kemerovo region, while only 2843 jobs are expected to be created, which is absolutely not enough to solve the problem.

In the Vladimir region, it is planned to create new jobs, thanks to the grant support of peasant (farmer) households and agricultural consumer cooperatives: in 2020 - 27 new permanent jobs, from 2021 to 2024 - 36 new permanent jobs, annually.

Social support measures, such as the payment of a monthly cash compensation for bread in the amount of 60 rubles, the provision of a quarterly cash payment (in return for receiving a food set) in the amount of 500 to 1,000 rubles, the provision of a monthly allowance for families with 4 or more children in the amount of 500 rubles, also will not have a significant impact on the well-being of citizens with an average per capita income below the subsistence level.

The Penza region presented only organizational measures.

The Udmurt Republic proposed a measure for financial and credit organizations to carry out measures to popularize among the population investments in stock market instruments, aimed at creating conditions for increasing the income of the population. We consider this measure to be incorrect due to the non-guaranteed income increase, risks of loss of funds.

A number of measures are of an organizational nature, the implementation of which in itself will not lead to an increase in the well-being of poor citizens. Among them:

creation of an interdepartmental working group for the implementation of measures aimed at achieving national goals of socio-economic development by 2024 to increase the real incomes of citizens, reduce the poverty level by half (for example, the Chechen Republic, Kaluga Region, the Republic of Khakassia);

organization of work to identify persons belonging to the category of the poor among recipients of social support measures (for example, Vladimir region, Sevastopol);

formation of a unified register of persons with incomes below the subsistence level (for example, the Chechen Republic, Kaluga Region, Sevastopol, Bryansk Region, KabardinoBalkar Republic, Republic of Khakassia);

monitoring prices for certain types of socially significant food products (for example, Sevastopol), etc.

These measures need to be supplemented with a financial component. As a positive example, we can cite the Nizhny Novgorod region, which provides for a detailed block of events for citizens included in the Register of citizens with incomes below the subsistence level: priority consideration for filling vacant positions; approval of an action plan ("road map") to promote employment of citizens experiencing difficulties in finding a job, as well as citizens at risk of dismissal.

Also in the Nizhny Novgorod region there is a definition of the list of medical organizations responsible for vaccination and treatment of citizens; carrying out work to 
create quota jobs at enterprises (organizations) related to the main types of economic activity, etc.

Such measures as ensuring state guarantees for the realization of the rights to receive secondary vocational education and vocational training in vocational educational organizations at the expense of the regional budget; provision of state guarantees for the implementation of the rights to receive public and free preschool, primary general, basic general, secondary general education and the provision of additional education for children in municipal educational organizations, the organization of the provision of general education in the regional state general educational organizations at the expense of the regional budget should be carried out on an ongoing basis and not be an additional guarantee to the poor population (for example, the Altai territory).

The implementation of measures to promote employment of citizens who applied to employment centers in order to find work, also cannot be an additional guarantee, since this is the main task of employment centers (for example, Volgograd region, Bryansk region).

The action plan of the Voronezh region spelled out: promoting self-employment of unemployed citizens, developing entrepreneurial initiative of unemployed citizens and creating jobs in the field of small business.

It is also proposed to organize vocational training for laid-off workers of enterprises and employees at risk of dismissal. The expected result of the implementation of this plan is the acquisition of skills that help to increase labor productivity and maintain employment. At the same time, it is indicated that funding from budgets of different levels is not required. The question is how these measures will be implemented.

One of the measures proposed by the constituent entities is an increase in the wages of certain categories of employees of state and municipal institutions of the budgetary sector, determined by the decrees of the President of the Russian Federation dated 07.05.2012 No. 597, dated 28.12.2012 No. 1688, dated 01.06.2012 No. 761.

For example, in the Kaliningrad and Kostroma regions, measures are aimed at all categories of workers, while in the Kabardino-Balkarian Republic - only at medical workers, and in the Voronezh region - at pedagogical workers of state municipal educational organizations. Thus, not all categories of workers provided for by decrees of the President of the Russian Federation in these regions are covered by an increase in wages.

In our opinion, the measures that will affect the incomes of families with incomes below the subsistence level, proposed by the constituent entities of the Russian Federation, are:

- provision of a monthly payment at birth after 01/01/2018 of the first child until he reaches the age of 1.5 years in the amount of the subsistence level established in the subject of the Russian Federation, the provision of a monthly cash payment for a child until he reaches the age of 3 years to families in need of support, at birth after 12/31/12 of the third or subsequent children in the amount of the subsistence minimum for children (for example, Ivanovskaya, Lipetsk, Ulyanovsk, Yaroslavl regions);

- provision of state gratuitous social payments to young families to improve their living conditions (Republic of Tatarstan - 30-35\% of the standard cost), provision of cash payments to families in which five or more minor children or three or more minor children were born and (or) raised, one of whom is a disabled child (including adopted children), for the purchase or construction of residential premises on the territory of a constituent entity of the Russian Federation (Primorsky Territory);

- setting the size of the parental payment for the supervision and care of pupils in preschool educational organizations for large families (with 3 or more children) at the level of $50 \%$ of the established parental payment, exemption of large families with an average per capita income below the subsistence level from paying for a kindergarten (Republic Tatarstan); 
- gratuitous provision of children in the first three years of life, who are on artificial and mixed feeding, from families with an average per capita income not exceeding the subsistence level per capita established in the territory of the subject of the Russian Federation, and children with chronic diseases, with special baby food (Republic Tatarstan), provision of adequate nutrition for children under the age of three from lowincome families (Ivanovo region);

- the introduction of an electronic certificate for medicines in the amount of 10 thousand rubles per year for children under 3 years old from families with an income below the subsistence level (Republic of Tatarstan), the purchase of medicines for children aged 0 to 6 years from low-income families (Ivanovo region );

- provision of free vouchers for organizing children's recreation and their health improvement for children in difficult life situations, aged from 6 to 15 years (Ivanovo region);

- provision of sets of school supplies for children in difficult life situations (Ivanovo region);

- provision of free and discounted travel for large families, orphans, regional and federal beneficiaries (Ivanovo region);

- implementation of a monthly cash payment for disabled children under the age of 18 who need constant care (Republic of Tatarstan);

- provision of benefits for a child who was simultaneously born in the composition of three or more children, within the framework of the regional project "Financial support for families at the birth of children" (Chechen Republic);

- the establishment of federal and regional social supplements to pensions up to the subsistence minimum of a pensioner in the constituent entity of the Russian Federation (Ivanovo, Chelyabinsk regions, Primorsky Krai, Chukotka Autonomous Okrug, etc.);

- granting subsidies to citizens for paying for residential premises and utilities (Republic of Tatarstan, Ivanovskaya, Chelyabinsk, Yaroslavl regions, Chukotka Autonomous Okrug);

- payment of a monthly allowance to citizens who have entered into a social contract: for assistance in finding a job and employment, for vocational training, etc. (Republic of Tatarstan);

- expansion of the directions of state social assistance on the basis of a social contract as part of the implementation of other measures aimed at overcoming the difficult life situation by the applicant (one-time payments for the purchase of medicines, essential goods, payment for preschool education) (Primorsky Territory);

- providing support to small and medium-sized businesses (Republic of Tatarstan), incl. Granting subsidies to the budgets of municipalities of the constituent entity of the Russian Federation to co-finance the costs of implementing activities of the relevant municipal programs (Tomsk Region).

It should be noted that Moscow and St. Petersburg did not provide action plans to achieve the national goal of halving poverty. In a reply letter, they indicated that in these regions the poverty rate is one of the lowest among the constituent entities of the Russian Federation and the share of the population with monetary incomes below the subsistence level is annually decreasing.

In some regions there are no benchmarks (with target values) (for example, the city of Sevastopol, the Perm Territory, the Kabardino-Balkarian Republic, the Kaliningrad Region, the Yamalo-Nenets Autonomous District) or the financial and economic justification for the action plan (for example, the Perm Territory, the Republic of Dagestan ). The Altai Territory does not have an action plan and a decision was made to prepare a draft regional program to increase the income of citizens and reduce the poverty level by October 1, 2019.

A good example of the structure can be the materials presented by the Altai Territory, namely: an assessment of the achieved level of the socio-economic plan, the standard of 
living of the population, a SWOT analysis is presented, measures aimed at reducing poverty, criteria and indicators characterizing the effectiveness of measures, organizational and methodological and informational support of the "road map".

Another good example. In the Primorsky Territory, a detailed analysis of the state of the problem and the socio-economic situation in the region was carried out, and the structure of poverty was assessed. As a result, measures were proposed to help reduce poverty, expected results and benchmarks for the implementation of the action plan ("road map"). It is especially worth noting that in the Primorsky Territory statistics are provided on the number of citizens who have emerged from the state of poverty based on the results of the proposed measures, and the forecast indicators of the number (total for all measures in 2019 - 18,841 people, in 2024 - 28,198 people).

In order to assess the real level and structure of poverty, the constituent entities of the Russian Federation have carried out (for example, the Chukotka Autonomous Okrug) or are planning to conduct (in particular, the Oryol, Murmansk, regions, Nenets Autonomous Okrug) sociological studies, which makes it possible to identify the factors that determine the inclusion of citizens among the poor and develop the necessary measures of social and economic support for each group of citizens.

The Ryazan region can also be attributed to a positive experience, where not only specific measures of social assistance are provided on the basis of a social contract, but also the amounts of the corresponding payments, the timing and number of families that are supposed to be covered by the social contract are indicated (in total - 4472 families).

2) Preparation of guidelines for the development of regional programs to reduce the proportion of the population with incomes below the subsistence level

Based on the analysis of the presented data on the implementation by the constituent entities of the Russian Federation of the pilot project on the first and second stages, researchers at the All-Russian Research Institute of Labor of the Ministry of Labor of the Russian Federation prepared guidelines for the development of regional programs to reduce the proportion of the population with incomes below the subsistence level.

The regional program for reducing the share of the population with incomes below the subsistence level (hereinafter referred to as the Regional Program) is a system of measures and indicators aimed at solving problems in the field of ensuring sustainable growth in real incomes of citizens, reducing the share of the population with incomes below the subsistence level. The regional program should contain specific measures implemented on the territory of a constituent entity of the Russian Federation, as well as the corresponding expenditures of the federal budget, budgets of constituent entities of the Russian Federation, budgets of state extra-budgetary funds and legal entities, and the planned results from the proposed measures.

Expected results of applying the Regional Program:

- building an effective system for taking citizens out of a difficult life situation by ensuring sustainable growth in real money income, improving the targeting of social services, and promoting employment;

- achievement of the indicator "poverty level, \%" in the constituent entities of the Russian Federation.

Methodological recommendations for the development of regional programs to reduce the proportion of the population with incomes below the subsistence level include the following sections.

1) Management of the implementation of the Regional Program.

In order to develop and implement the Regional Program, it is recommended to create a working body (commission, council, group, etc.) under the leadership of a senior official (head of the highest executive body of state power) of the constituent entity of the Russian Federation. 
The working body (commission, council, group, etc.) should be formed from representatives of the executive authorities of the constituent entity of the Russian Federation, territorial subdivisions of federal executive bodies and state extra-budgetary funds, interested organizations of federal and regional subordination, local self-government bodies of urban districts, municipal districts and settlements, professional communities, public organizations, active citizens.

The functions of the working body include:

- organization of analysis of the current situation related to the standard of living of the population, and control of its implementation;

- development and approval of the Regional Poverty Reduction Program, with the subsequent introduction of amendments to it, making decisions related to the reduction of the poverty level of the population of the constituent entity of the Russian Federation;

- organization of monitoring the implementation of the Regional Program and assessment of its effectiveness.

It is recommended to hold meetings of the working body as needed, but at least once a quarter. The executors of the Regional Program send reports on the implementation of the activities of the Regional Program to the working body.

2) The procedure for the development of the Regional Program.

In order to develop Regional Programs, the constituent entities of the Russian Federation should analyze the current situation (identify the causes and characteristics of poverty in the constituent entity of the Russian Federation), determine the planned indicators, develop measures and evaluate the results of their implementation for the entire analyzed period.

Monitoring and evaluation is recommended to be carried out: upon achievement of the planned indicators of the Regional Program - on a quarterly basis, upon the implementation of planned activities - annually.

To achieve a positive effect from the implementation of the Regional Program, the working body must develop intermediate performance indicators for the executive authorities and local government bodies of the constituent entity of the Russian Federation and draw up them in the form of a draft detailed schedule (hereinafter referred to as the detailed schedule).

The draft detailed plan-schedule for the implementation of the Regional Program is drawn up annually for the planning period: for planned indicators - a quarter on an accrual basis, for planned activities - for a year. A detailed timetable is an integral part of the Regional Program.

When forming a set of main activities, the possibility of identifying control events of the Regional Program (hereinafter - the control events of the program) within the framework of their implementation should be taken into account, allowing to evaluate the intermediate or final results of the implementation of the main activities. The detailed schedule indicates the expected results of the activities and highlights the milestones of the Regional Program, if necessary.

If the deadlines for the implementation of measures go beyond the planning period, then the detailed schedule for the activities indicates the dates that go beyond the planning period, and for control events - within the planning period.

The regional program must be approved by the highest official (head of the highest executive body of state power) of the constituent entity of the Russian Federation and agreed with the Ministry of Labor and Social Protection of the Russian Federation.

Adjustments to the Regional Program must be made as needed. It is recommended to reflect in the Regional Program the issue of organizing interdepartmental interaction of executive authorities of the constituent entities of the Russian Federation, territorial bodies 
of the federal tax service, Rosreestr, the Ministry of Internal Affairs of the Russian Federation of each body in achieving the set goals.

\section{Results and discussions}

In its most general form, both environmental management and environmental management can be defined as a complex multifaceted activity aimed at achieving the environmental goals of projects and programs.

In Russian literature (including translations of ISO 14000 documents), the term "environmental management" has been replaced by "environmental quality management", and in some cases by "environmental management".

At the same time, for these concepts, based on the analysis of existing regulatory documents, educational and methodological literature, and the practice of activity, a number of significant differences can be distinguished, determined by the subjects of environmental management and environmental management, the motivation of activities, the role of responsible persons, attitude to the results of activities, etc.

Thus, Environmental Management is the activity of state bodies and economic entities, mainly aimed at complying with the mandatory requirements of environmental legislation, as well as at developing and implementing relevant projects and programs.

Environmental management is an initiative and effective activity of economic entities aimed at achieving their own environmental goals, projects and programs developed on the basis of the principles of the effectiveness of the entity's environmental activities.

The main objectives and the corresponding criteria for assessing their achievement in environmental management are associated with continuous improvement processes. A consistent improvement from year to year should be achieved in all environmentally significant aspects of the activities of economic entities, where it is practically achievable.

In general, such an improvement cannot be imitated and falsified, which creates the necessary basis for assessing the environmental viability of economic agents.

Thus, effective environmental management provides an enterprise with a credit of trust in relations with all stakeholders in its activities. This is the main advantage of environmental management over traditional formal environmental management.

The most important driver for achieving environmental sustainability is the fight against poverty. The authors identified the following guidelines for solving this problem in Russia.

Methodological recommendations for the development of regional programs to reduce the proportion of the population with incomes below the subsistence level include the following sections.

1) Management of the implementation of the Regional Program.

In order to develop and implement the Regional Program, it is recommended to create a working body (commission, council, group, etc.) under the leadership of a senior official (head of the highest executive body of state power) of the constituent entity of the Russian Federation. The working body (commission, council, group, etc.) should be formed from representatives of the executive authorities of the constituent entity of the Russian Federation, territorial subdivisions of federal executive bodies and state extra-budgetary funds, interested organizations of federal and regional subordination, local self-government bodies of urban districts, municipal districts and settlements, professional communities, public organizations, active citizens.

2) The procedure for the development of the Regional Program.

In order to develop Regional Programs, the constituent entities of the Russian Federation should analyze the current situation (identify the causes and characteristics of poverty in the constituent entity of the Russian Federation), determine the planned 
indicators, develop measures and evaluate the results of their implementation for the entire analyzed period. Monitoring and evaluation is recommended to be carried out: upon achievement of the planned indicators of the Regional Program - on a quarterly basis, upon the implementation of planned activities - annually.

\section{Conclusion}

Based on the analysis, it was revealed that there is a clear relationship between the problems of poverty and the environment. Over the entire period of its existence, mankind has not solved two main issues: impoverishment and ecological state. Unfortunately, interests, not values, dominate the world today. However, individual interests do not provide opportunities for positive change.

There is no need to prove (and this is immediately obvious when you come to another country) that the standard of living of people directly depends on ecology, on the state of the environment - in other words, whether they adhere to the principles of sustainable development. Improving the quality of life of people is impossible without improving the environment in which they live.

In order to solve this problem in Russia the authors propose to use the regional programs for reducing the share of the population with incomes below the subsistence level (hereinafter referred to as the Regional Program). Regional programme is a system of measures and indicators aimed at solving problems in the field of ensuring sustainable growth in real incomes of citizens, reducing the share of the population with incomes below the subsistence level. The regional program should contain specific measures implemented on the territory of a constituent entity of the Russian Federation, as well as the corresponding expenditures of the federal budget, budgets of constituent entities of the Russian Federation, budgets of state extra-budgetary funds and legal entities, and the planned results from the proposed measures.

\section{References}

1. Our Common Future, From One Earth to One World, UN Documents Gathering a body of global agreements, http://www.un-documents.net/ocf-ov.htm\#I

2. The Millennium Development Goals Report, 2009, United Nations, https://www.un.org/millenniumgoals/pdf/MDG_Report_2009_ENG.pdf

3. A. Lusigi, Linking Poverty to Environmental Sustainability, UNDP-UNEP Poverty Environment Initiative, https://www.povertyandconservation.info/docs/20080524UNDP-UNEP_Poverty_Environment_Initiative.pdf

4. Ministry of Labor and Social Protection of the Russian Federation, official site

5. Federal State Statistics Service, official site, https://rosstat.gov.ru/

6. A. Bashkatova, Poka naseleniye bedneyet, strana ne stanet velikoy derzhavoy, Nezavisimaya gazeta 4 (2019)

7. Ye. Gerasimova, Nishcheta v rannem vozraste sil'no vliyayet na cheloveka, Nezavisimaya gazeta 8 (2020)

8. Ye. Grishina, Dokhody i uroven' bednosti naseleniya: tekushchiye trendy, Ekonomicheskoye razvitiye Rossii 24, 5, 64-67 (2017) 
9. I.I. Yeliseyeva, Izmereniye bednosti v Rossii: vozmozhnosti i ogranicheniya, Voprosy statistiki 8, 70-89 (2017)

10. L.S. Rzhanitsyna, Bednyye v Moskve: sposoby izmereniya, mery sotsial'noy politiki, Sotsiol. Issled 10, 77-89 (2018)

11. Ye.D. Slobodenyuk, Gde prolegayet «cherta bednosti»v Rossii?, Voprosy ekonomiki 1. 104-127 (2018)

12. O. Solov'yeva, Rossiyskaya bednost' zarazila razvityye strany, Nezavisimaya gazeta 4 (2019)

13. V. Fadeyev, Neravenstvo i bednost', Ekspert 4, 18-22 (2019) 